Discussion Paper No. 09-079

Fixing the Leak:

Unemployment Incidence Before and After the 2006 Reform of Unemployment Benefits in Germany

Stephan Dlugosz, Gesine Stephan, and Ralf A. Wilke

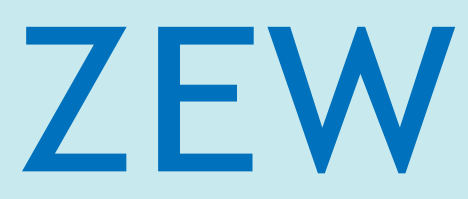

Zentrum für Europäische Wirtschaftsforschung $\mathrm{GmbH}$ Centre for European Economic Research 


\title{
Discussion Paper No. 09-079 \\ Fixing the Leak: \\ Unemployment Incidence Before and After the 2006 Reform of Unemployment Benefits in Germany
}

\author{
Stephan Dlugosz, Gesine Stephan, \\ and Ralf A. Wilke
}

Download this ZEW Discussion Paper from our ftp server:

ftp://ftp.zew.de/pub/zew-docs/dp/dp09079.pdf

Die Discussion Papers dienen einer möglichst schnellen Verbreitung von neueren Forschungsarbeiten des ZEW. Die Beiträge liegen in alleiniger Verantwortung der Autoren und stellen nicht notwendigerweise die Meinung des ZEW dar.

Discussion Papers are intended to make results of ZEW research promptly available to other economists in order to encourage discussion and suggestions for revisions. The authors are solely responsible for the contents which do not necessarily represent the opinion of the ZEW. 


\section{Non Technical Summary}

The law on labour market reforms has severely limited the maximum benefit period for the elderly; with cuts of up to 14 months, depending on the age group. Our paper examines this natural experiment and shows that for the age groups in question, the transition rates from employment to unemployment rose significantly in the three months prior to the reform. For the average employee in the age group 57 to 64 years, the monthly probability of transition was approx. 120 percent higher than had been expected without reform. In the postreform time period up to 2007, the monthly entry rates of elderly persons into unemployment fell significantly; among the 57 to 64-yearolds they were well over 20 percent lower than without the reform. A considerable share of the low entries in the post-reform time period is most likely due to the fact that transitions were included as part of the months before the reform. Since maximum benefit periods have partly been extended at the beginning of 2008, it was unfortunately not possible to identify the exact long-term effect of the reform. A cautious assessment of the effects of the financial reform nevertheless shows an annual cost-saving potential for unemployment insurance of 3.66 to 4.22 billion euros, compared to the pre-reform period. This amount corresponds to approx. 13 to 15 percent of the unemployment benefit expenditures in 2004. The reform thus played a significant role in subsequent reductions of unemployment insurance contributions. 


\section{Das Wichtigste in Kürze}

Das Gesetz zu Reformen am Arbeitsmarkt schränkte ab Februar 2006 die Bezugshöchstdauern des Arbeitslosengeldes für Ältere stark ein; je nach Altersgruppe um bis zu 14 Monate. Wir untersuchen dieses natürliche Experiment und zeigen: Bei den betroffenen Altersgruppen stiegen die Übergangsraten aus Beschäftigung in Arbeitslosigkeit in den drei Monaten vor der Reform deutlich an: Bei einem durchschnittlichen Arbeitnehmer der Altersgruppe 57 bis 64 war die monatliche Übergangswahrscheinlichkeit sogar um etwa 120 Prozent höher, als ohne Reform zu erwarten gewesen wäre. Im Nachreform-Zeitraum bis Ende 2007 sanken die monatlichen Eintrittsraten Älterer in Arbeitslosigkeit deutlich ab; sie lagen bei den 57-64 Jährigen um gut 20 Prozent niedriger als ohne Reform. Ein beträchtlicher Teil der geringeren Eintritte im Nachreform-Zeitraum dürfte darauf zurückzuführen sein, dass Übergänge in die Monate vor der Reform vorgezogen wurden. Da der Gesetzgeber die Bezugshöchstdauern bereits Anfang 2008 teils wieder verlängerte, lässt sich der exakte langfristige Reformeffekt leider nicht identifizieren. Dennoch zeigt eine vorsichtige Abschätzung der finanziellen Reformwirkungen ein Einsparungspotential bei der Arbeitslosenversicherung von jährlich 3,66 bis 4,22 Milliarden Euro im Vergleich zum Vorreform-Zeitraum. Dies entspricht etwa. 13 bis 15 Prozent der Aufwendungen für Arbeitslosengeld im Jahr 2004. Somit hat diese Reform maßgeblich spätere Senkungen der Beitragssätze zur Arbeitslosenversicherung ermöglicht. 


\title{
Fixing the leak: Unemployment incidence before and after the 2006 reform of unemployment benefits in Germany*
}

\author{
Stephan Dlugosz $\rceil^{\dagger}$ Gesine Stephan ${ }^{\ddagger}$ Ralf A. Wilke ${ }^{\S}$
}

From 2002-2004, the German government passed several laws that curtailed the generosity of the unemployment compensation system. One of the most ambitious changes was a considerable reduction in unemployment benefit entitlement lengths for older unemployed, which was effective during 2006 and 2007. We apply a difference-in-differences approach to show that the highly disputed reform induced a considerable decline in unemployment incidence among older workers. It thus sealed an important leak in the unemployment insurance system. Furthermore, we find a strong anticipation effect; unemployment entries of elderly workers peaked during the months preceding the reform.

Keywords: unemployment incidence, policy evaluation, administrative data

JEL: J63, J65

\footnotetext{
* We thank Bernd Fitzenberger and Elke Jahn for helpful discussions and comments, and Holger Bonin, Michael Feil, Barbara Hanel, Barbara Hoffmann, Walter Schaal and Christina Wübbeke for helpful hints. Dlugosz and Wilke are supported by the German Research Foundation through the Statistical Modelling of Errors in Administrative Labour Market Data grant. Wilke is also supported by the Economic and Social Research Council through the Bounds for Competing Risks Duration Models using Administrative Unemployment Duration Data (RES-061-25-0059) grant. The data used in this paper have been kindly provided by the ITM unit of the Institute for Employment Research.

$\dagger$ ZEW Centre for European Economic Research, L7 1, 68161 Mannheim, Germany E-mail: dlugosz@zew.de

¥ Corresponding author, IAB Institute for Employment Research and University of ErlangenNuremberg, Regensburger Str. 104, 90478 Nuremberg, Germany, E-mail: gesine.stephan@iab.de, Phone: ++49 911179 5850, Fax: ++49911 1798976

§ School of Economics at the University of Nottingham, PSI Policy Studies Institute London, and ZEW Centre for European Economic Research Mannheim, Nottingham NG7 2RD, United Kingdom, E-mail: ralf.wilke@nottingham.ac.uk
} 


\section{Contents}

1. Introduction 1

2. Theory and Literature Review 2

3. The 2006 Reform of Unemployment Benefits 4

4. Data and Descriptive Statistics 7

5. Econometric Analysis 12

6. Fiscal Benefit Analysis 19

7. Conclusions 22

A. Institutional Background Supplement 26

B. Additional Tables 28 


\section{Introduction}

Economic theory suggests that unemployment benefits (UB) reduce incentives to work (Moffitt and Nicholson, 1982; Mortensen, 1970). The effect of UB on labour market outcomes might be particularly strong for older individuals, because workers as well as firms account for expected streams of unemployment benefits when determining the optimal timing of (early) retirement (Hutchens, 1999; Stock and Wise, 1990). This paper investigates empirically how labour market institutions, in particular the system of unemployment compensation and its use as a pathway into early retirement, affect transitions out of employment into unemployment. We analyse the effects of important legislative changes, which strongly modified the out-of-work options for older individuals: During 2006, Germany has seen a radical shortening of unemployment benefit entitlement periods for the elderly. Our paper presents first results on the effects of this highly debated policy change on individual labour market outcomes.

From the 1980s until 2006, the German unemployment benefit system guaranteed constant and high compensation streams (up to 32 months) for elderly workers. It thus provided a popular bridge between the exit out of regular employment and the entry into old age pension. Unemployment incidence was high among older workers with long tenure, and their labour force participation rate was also exceptionally low (OECD, 2003). In the mid 1990s, unemployment rates for the elderly peaked at about 20-25\% and the situation became more and more financially untenable. Since the second half of the 1990s, several reforms reduced the generosity of the unemployment compensation and the pension system, with the aim to postpone workers' exit out of employment and their entry into retirement. While changes were rather moderate until the year 2002, the pace of reforms considerably increased in the period 2003-2006. A key element of these policy reforms was the reduction in maximum entitlement lengths for unemployment benefits, which became effective in February 2006.

This paper presents a first empirical analysis of the effects of the 2006 reform on individual unemployment incidence. The reform affected only older age groups and can thus be interpreted as a natural experiment. This allows us to identify the reform effects using a difference-in-differences approach. We obtain strong evidence that unemployment incidence considerably declined in response to the reform. Our findings confirm previous empirical results for earlier policy changes in Germany and Finland (e.g. Fitzenberger and Wilke, 2010; Kyyrä and Wilke, 2007). Moreover, we find a considerable anticipation effect just before the reform that led to a peak in the inflow to unemployment during the 
winter 2005/2006. The size of this effect is surprising, as legal regulations were designed to prevent exactly this anticipation effect. Thus, our results suggest that legislation was not able to fully absorb economic incentives to exploit the old system as far as possible. Due to anticipation of the reform and the short period until the next reform took place in early 2008, our analysis cannot exactly identify the longer-term (steady-state) reform effect. Nevertheless, our results suggest that the reform was successful by sealing an important leak in the German unemployment insurance system, as the decrease in unemployment incidence after the reform clearly offsets the anticipation effect.

The paper is structured as follows. Section 2 gives a short review of the theoretical and empirical literature, while Section 3 describes the institutional setup in more detail. Section 4 introduces the data and Section 5 presents estimation results. Based on these estimates, Section 6 provides a fiscal benefit analysis of the reform from the viewpoint of the Federal Employment Agency. The last section provides a concluding discussion.

\section{Theory and Literature Review}

Economic theory suggests that less generous unemployment compensation makes the state of unemployment less attractive. The competitive labour supply model as well as the basic job search model (Moffitt and Nicholson, 1982, Mortensen, 1970, see also Cahuc and Zylberberg, 2004, Chap. 1 and 3) show that reservation wages increase with the generosity of unemployment benefits. As labour market institutions do not operate in isolation (e.g. Boeri and van Ours, 2008, Chap. 13), we have to take into account the interplay between the system of unemployment benefits, retirement programs, and employment protection.

Workers as well as firms optimise their expected present value of future utility or profit, respectively. A worker will quit once utility from retirement exceeds utility from remaining employed. In a simple model of the worker's optimisation decision, it can be shown that postponing retirement increases income over the remaining life period, while time to derive utility from being retired decreases; thus that there must be some optimal retirement age (e.g. Boeri and van Ours, 2008, Chap. 6). Taking into account uncertainty over future income streams, Stock and Wise (1990) developed an option value model of the (irreversible) retirement decision, where the retirement decision is reassessed every period when new information on future earnings arrives. Several recent papers presented dynamic programming models of the retirement decision and presented empirical applications (e.g. Hakola and Määtänen, 2009; Karlstrom et al., 2004). In the 
context described by us in more detail in Section 3, achievable consumption and leisure paths are derived not only from expected future earnings and retirement pensions, but also from achievable streams of unemployment benefits.

However, firms will often be interested in a separation before a worker's optimal retirement age (or the mandatory retirement age) has been reached. Boeri and van Ours (2008, Chap. 6.3.2) discuss the relationship between age and productivity and conclude that the objective relationship is difficult to establish (results from the literature are ambiguous); nonetheless, employers seem to have strong opinions about a decreasing productivity of workers with age. If dismissals are not enforceable due to employment protection (e.g. Jahn, 2009), or unwarranted due to implicit contracts or fairness considerations (e.g. Gerlach et al., 2008), both parties may negotiate an agreement, often accompanied by some kind of compensation paid by the firm to the worker. Bentolila and Bertola (1990) developed a model of a firm's optimal employment policy in the presence of hiring and firing costs and showed that a firm reduces its labour force, if the expected present values of further employment are lower than firing costs. Hutchens (1999) presented a model where the firm and its workers negotiate a three-period contract over wages, private pensions, and employment probabilities. While the worker is employed during the first and retired during the third period, his employment probability during the second period is a function of his productivity at work and at home. In this context, the availability of second-period social security benefits would raise the income of second-period retirees and thereby reduce a firm's costs to reach a mutual agreement on second period retirement.

There is a broad empirical literature on the effect of changes in the unemployment compensation system on unemployment duration (e.g. for recent studies Addison and Portugal, 2008; Lalive et al., 2006; Lalive, 2007, 2008; Lee and Wilke, 2009; Müller et al., 2007). Fewer studies analyse - as we do - the impact of such changes on unemployment incidence. Empirical evidence relies predominantly on difference-in-differences estimators (DiD), exploiting reforms in the length of unemployment benefit entitlements that affected different age groups differently. For Germany, a number of papers have investigated the reforms of the 1980s and 1990s. Fitzenberger and Wilke (2010) compared unemployment entries and unemployment duration before and after a UB reform that took place in the 1980s and extended benefit durations for the elderly unemployed significantly. Whereas the reform had only a small effect on unemployment between jobs, it increased entries into permanent non-employment for elderly workers. Müller et al. (2007) showed that increasing age thresholds for maximum eligibility during 1997 reduced the 
unemployment incidence and in particular early retirement. Hanel (2008) approached the problem from the viewpoint of an introduction of permanent benefit reductions for early retirees that was enacted also during 1997. She found that this reduction led to a postponement of retirement entries by about fifteen months and a delay of employment exits by about nine months. Empirical evidence for other countries obtained similar results. For Austria, Winter-Ebmer (2003) analysed the quasi-experimental situation arising from a large extension of benefit duration in certain Austrian regions. He showed that unemployment entry rose considerably as a result of the new law. For Finland, Kyyrä and Wilke (2007) found that increasing the age threshold from which UB could be utilised as an "unemployment tunnel" into early retirement decreased unemployment entries of the affected age group.

\section{The 2006 Reform of Unemployment Benefits}

The German unemployment compensation system consists of two main elements. First, entitled contributors receive UB (Arbeitslosengeld 1) by the unemployment insurance for a limited time period; its amount depends on former wages. Second, needy unemployed job-seekers and their household members are entitled to means-tested and tax-financed unemployment assistance (Arbeitslosengeld 2, UA) since 2005. Contrary to the period before 2005, its amount does not depend on former wages. The Federal Employment Agency (Bundesagentur fuer Arbeit, BA) in Nuremberg is the official government body that administrates the unemployment insurance according to the Social Security Code (Sozialgesetzbuch, SGB). In order to qualify for UB, workers or employees need to have been in regular employment at least 12 months during the past three years until 2005, and during the past two years since 2006. This generates at least 6 months of UB entitlements, while the maximum duration depends on the calendar time period and on the length of the qualifying employment period. Until the end of 2007, unemployed persons of at least age 58 had the opportunity to withdraw from job search (and registered unemployment), while still receiving UB (see Appendix A). Even though workers and firms fund German unemployment insurance, there is no comparable experience rating system as in the US. Thus, lay-offs do not increase social security contribution rates of firms.

The maximum entitlement length for UB in Germany was subject to several changes since the 1980s. While it was 12 months independent of age until the mid 1980s, it was extended to up to 32 months for those aged at least 54. In 1997, the age threshold for 
extended entitlement lengths was raised by a few years, such that the minimum age for 32 months of entitlement increased to 57. This regime was valid until February 2006, when entitlement lengths were substantially shortened to a maximum duration of 18 months (see also Table 1); maximum entitlement lengths for older individuals diminished by up to 14 months for those aged $52-54$ and aged $>56$. However, the variation in actual UB entitlement lengths did not necessarily change payment streams for low-income earners (see Appendix A). The shortening was one of the key elements in the series of the so called "Hartz-Reforms" of the coalition government by Social Democrats and the Green Party, which were enacted during the period 2003-2006.

This paper analyses the effects of the aforementioned 2006 UB reform on the unemployment incidence of entitled older individuals. Because entitlements for younger individuals were not affected, the policy change involved a natural experiment, with well defined control and treatment groups. Furthermore, the 2006 reform affected all individuals who lost their job after the $31^{\text {st }}$ of January 2006, while the stock of UB claimants was unaffected. Therefore, the design of this policy change set economic incentives to advance planned dismissals to an earlier date. As it was unpopular with large parts of the voting population, the successive government (grand coalition of Christian Democrats and Social Democrats) withdrew the 2006 reform to a large extent in 2008, by re-extending the UB entitlement lengths to up to 24 months. This new regime was applied not only to new entries into unemployment, but also to those unemployed at that point of time. Our empirical analysis focuses on the 2006 reform; comprehensive individual data for the period after 2007 are not available yet. Nonetheless, labour market outcomes in late 2007 may have been already affected due to anticipation of the 2008 reform.

Two other policy changes were enacted at the beginning of 2006. First, as has been mentioned above, the qualification period for unemployment benefits has been reduced for all workers. Second, since 2006, a previously granted tax-free allowance for severance pay (11,000 Euro) has been abolished. Because we would expect severance payments to be larger for older workers with longer tenure, this modification has potentially reinforced the effects of the UB reform. Due to a lack of data on severance payments we are unfortunately, not able to separate between these two effects. However, the financial consequences of changes in taxation might be bypassed if non-cash benefits can be offered instead.

It is well known that the extension in UB entitlement lengths during the 1980s has led to a sharp increase in the incidence of unemployment for older workers (Fitzenberger 
Table 1: The 2006 reform of maximum entitlement length for UB in Germany.

\begin{tabular}{lrrr}
\hline & \multicolumn{3}{c}{ maximum UB entitlement length in months } \\
age group & until $1 / 2006$ & $2 / 2006$ to $12 / 2007$ & reduction \\
\hline$<45$ & 12 & 12 & 0 \\
$45-46$ & 18 & 12 & 6 \\
$47-51$ & 22 & 12 & 10 \\
$52-54$ & 26 & 12 & 14 \\
$55-56$ & 26 & 18 & 8 \\
$>56$ & 32 & 18 & 14 \\
\hline
\end{tabular}

and Wilke, 2010). Workers of age 57 and older could utilise the long entitlement length for UB as a bridge between employment and old age pensions. In 1997, this form of early retirement became more difficult as not only the unemployment insurance system, but also the pension system underwent several important changes (see Appendix A). Pension reforms were, however, implemented gradually and over very long transitions periods. Thus their effects should not interfere - or at least not interfere strongly — with the effects of the (discontinuous) UB reform analysed by us.

Furthermore, several legal requirements could partly block pathways into early retirement. First, dismissal protection for older workers with long tenure is rather strong (see Appendix A). In particular, employment relationships of long-tenured workers in large firms are likely to be sensitive to changes in the unemployment benefit system. Jahn (2009) points out that it is nearly impossible for larger firms in Germany to dismiss older workers with long tenure due to social criteria; thus they have to "buy out" older workers by means of severance pay. Such separations are particularly costly and thus, large firms would be particularly likely to restrain from early retirement offers after a reduction in expected streams of unemployment compensation. Second, from the end of 2003 up to the 2006 reform, firms (except for small firms) had to partly or fully refund UB transfers for dismissed older workers with longer tenure (§147a SGB III); the underlying idea was to prevent anticipation effects of the reform. There are, however, important exceptions for firms and workers, which may offer opportunities to bypass the law. In our empirical analysis, we are also able to check whether the implementation of this law has been successful in the sense that it fully deterred anticipation effects of the shortened benefit duration. Third, employees who voluntarily quit their job suffer a cut-off period without UB receipt that shortens the remaining period of UB receipt. The length of the period was increased several times since the 1980s and has amounted 
to 12 weeks during the time period under investigation ( $\$ 144$ SGB III).

Based on the design of the 2006 reform and our economic reasoning in Section 2, we formulate the following three hypotheses, which we will analyse in our empirical analysis:

- The reduction in unemployment incidence for older workers depends on the strength of the treatment. We therefore expect the largest drop in unemployment entries for the aged $52-54$ and aged $>56$.

- The reform effect is larger for older employees with long tenure in large firms. Larger firms cannot easily dismiss older workers with long tenure due to social criteria and have to buy them out. Therefore, they have to offer higher severance payments (cash and other benefits) and use unemployment benefits as a subsidy to reach a mutual agreement.

- There is a sharp increase in unemployment incidence briefly before the reform due to anticipation behaviour.

\section{Data and Descriptive Statistics}

For our empirical analysis, we use the Integrated Employment Biographies (IEB) of the Institute for Employment Research (IAB) which is a merged administrative data set. These data contain daily spell information about employment periods subject to social security contributions (excludes self employment and life time civil servants), job seeking periods, participation in active labour market programmes, and UB/UA claim periods ${ }^{1}$. For more details on these data see Oberschachtsiek et al. (2009). Our sample covers the period 2000 to 2007, whereas employment and benefit claim spells are available since 1993. Our sample is a $2 \%$ random sample of employees born before 1970 . For our empirical analysis, we organise the data in form of a monthly panel of workers. We restrict our sample to individuals aged 40-64, who (would have) had the maximum UB entitlement lengths under the pre-reform regime. Because special regulations apply to seasonal unemployment in the construction sector, we exclude it from the following analysis.

Age-specific unemployment rates in Germany are heavily driven by changes in the definition of unemployment due to modifications of the aged 58+ rules in 2003 and in

${ }^{1}$ The data do not distinguish between employee- and employer-initiated separations. Additional calculations based on the German Socio-Economic Panel suggest that the share of employee-initiated separations amounts to less than 10 percent for persons aged 40 and older. 
Figure 1: Age-specific UB recipient rates from January 2003 to December 2007 based on UB claimants and workforce with maximum entitlements only. Source: IEB, own results.

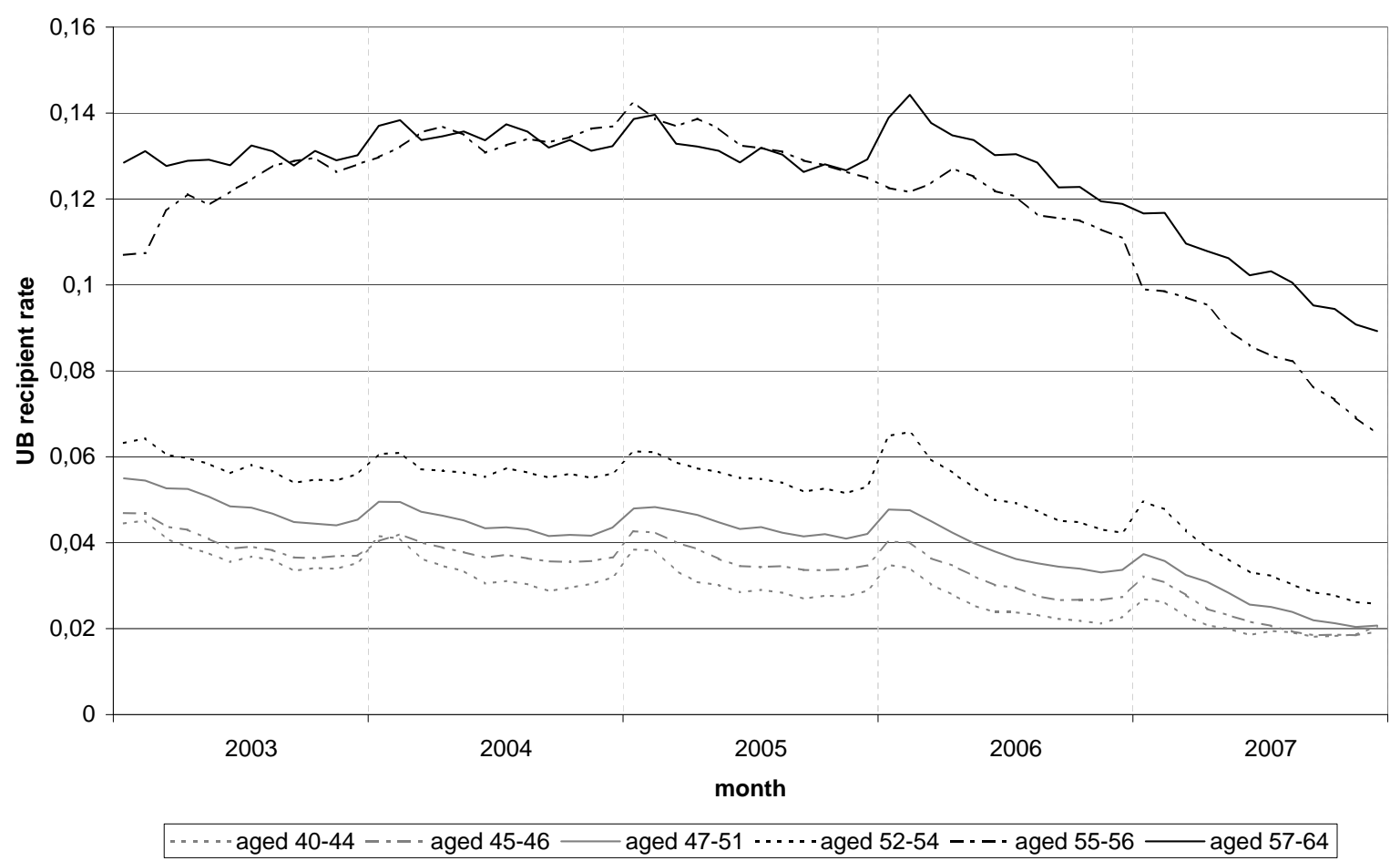

2008 (Appendix A). Therefore, we present age group specific rates of UB claimants with maximum entitlement lengths (cf. Table 1) as a share of the eligible population instead. Figure 1 shows that there has been a general increase in UB claimant rates until the end of 2004; rates were mainly stable during 2005 and decreasing after 2005. These general developments can be explained by increasingly favourable business conditions in the latter years. Figure 1 also suggests that the gap between claimant rates for older and prime age unemployed increased within the less favourable business environment until 2004, and that it decreased during the boom period (2006-2007). Furthermore, we observe a particularly strong decline in the UB claimant rates after the reform in February 2006. Moreover, there are considerable peaks in the UB claimant rates of aged 57-64 and 52-54, the two most affected groups by the UB reform, in late 2005 and early 2006. As there are none or much smaller increases for other age groups, this provides first empirical evidence for anticipation behaviour before the reform. While the disproportional changes in the rates provide some descriptive evidence for a reform effect, it is difficult to establish a clear link to unemployment incidence as the rates 
are also affected by the stock of unemployed or UB claimants and by unemployment duration. In our econometric analysis, we focus on changes in unemployment incidence.

Because we analyse a reform of the UB system, we restrict our sample to individuals who were eligible for UB when becoming unemployed. Thus, in our empirical analysis, we define a transition to unemployment as a transition from employment subject to social security contributions to claiming UB (Arbeitslosengeld 1$)^{2}$. Figure 2 displays the probability of becoming unemployed by age and year ${ }^{3}$. The unemployment incidence is computed for workers who are eligible to the maximum unemployment benefit according to Table 1 and became unemployed during the current year. Before the UB reform, those who were 57 and older at the beginning of their unemployment period were eligible for 32 months, i.e. more than 2.5 years of UB. This induced a higher transition rate to unemployment, which is indicated by a jump in the graph at the age of 57 . The incidence peaked at an age of 60 and then declined for older persons, as other ways into early retirement became more attractive. Just before the 2006 reform, unemployment incidence strongly increased for those aged 57+. After January 2006-when UB entitlement lengths were reduced by more than $50 \%$ for the aged $57+$ - unemployment incidence peak at an age of 63 .

Figure 3 shows monthly transition rates to unemployment during a certain month for different age groups. Transitions occur more frequently at the end of the year or quarter, which leads to peaks in the incidence. This pattern is more apparent for the oldest age group $57+$. Furthermore, there is a much higher peak at the end of 2005 for the age group $57+$ and also - but less prominent - for the other age groups. Similar to Figure 2, this indicates the presence of an anticipation effect just before the UB reform from November 2005 until January 2006. Moreover, unemployment incidence for the oldest age group drops from about 0.005 to slightly above 0.0025 after the UB reform,

${ }^{2}$ Due to cut-off periods or temporary drop outs, for example, UB claim spells do not always begin at the end of the previous employment spell. In these cases, it is not observable from the data whether there is an immediate transition to unemployment or a temporary inactivity period. As the number of these cases is rather small in our sample, our empirical results are robust with respect to the maximum allowed gap. We checked this for gaps of up to six months. Our following empirical results are obtained by allowing for gaps of up to three months between the end date of an employment spell and the start date of a subsequent UB claim spell.

${ }^{3}$ More specifically, the probability of becoming unemployed in year $t$ for $a$ years old workers is computed as

$$
1-\prod_{m=1}^{12}\left[1-p_{a, \ell, m}\right],
$$

where $p_{a, \ell, m}$ is the monthly layoff rate among workers aged $a$ for month $m$ of year $\ell$, which is defined as the ratio of workers with eligibility for the maximum entitlement length becoming unemployed during month $m$ to otherwise equal workers who were still employed at the end of month $m$. 
Figure 2: Annual transition rates from employment to unemployment by age and year. Source: IEB, own results.

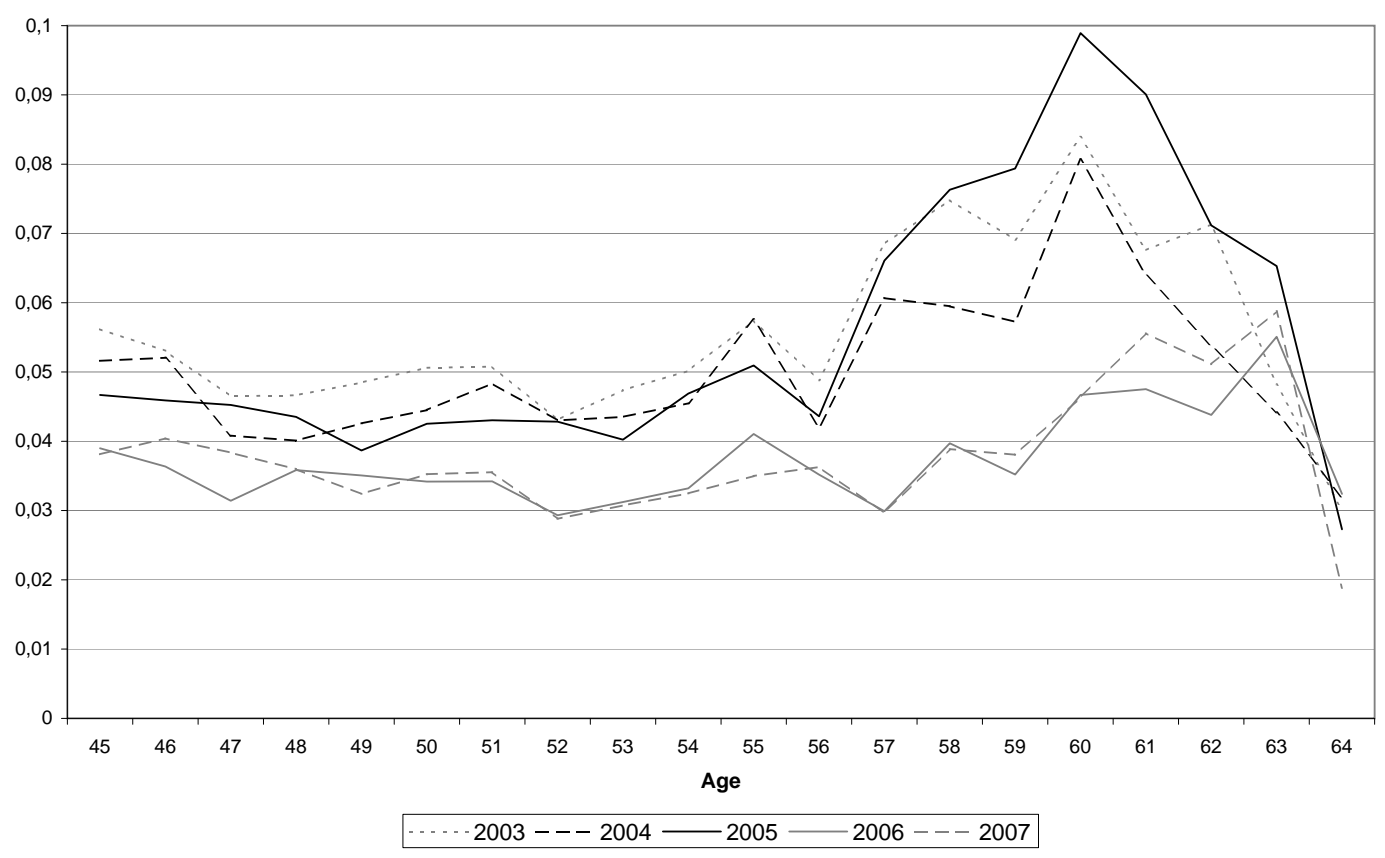

while the decline for the other age groups is much smaller.

As described in Section 3, there are several laws that are supposed to prevent early retirement at the expense of the unemployment insurance. These include cut-off periods for unemployed who voluntarily quit their job; since 2003, large firms are obliged to refund unemployment benefits for dismissed older workers with more than 10 years of tenure. However, a brief study of the official statistics of the Federal Employment Agency showed that the numbers of such cases are rather low: In April 2006, the stock of unemployment benefit recipients of age 55 and older for whom unemployment benefits had to be refunded by the firm peaked at 5,300 cases (the average stock 2005-2006 amounted to about 430,000 persons). The number of cut-off individuals within the same age group due to quitting peaked in February 2006 at about 2,300 entries, nearly doubling the average number of cut-off cases (average monthly entries in unemployment 2005-2006 amounted to about 18,000). While we cannot say anything about the ex-ante (threat) effects of these regulations, we conclude that they have been applied ex-post only in comparatively few cases and were not able to entirely eliminate anticipation behaviour just before the reform. 
Figure 3: Monthly unemployment incidence by time, year and age group. Source: IEB, own results.
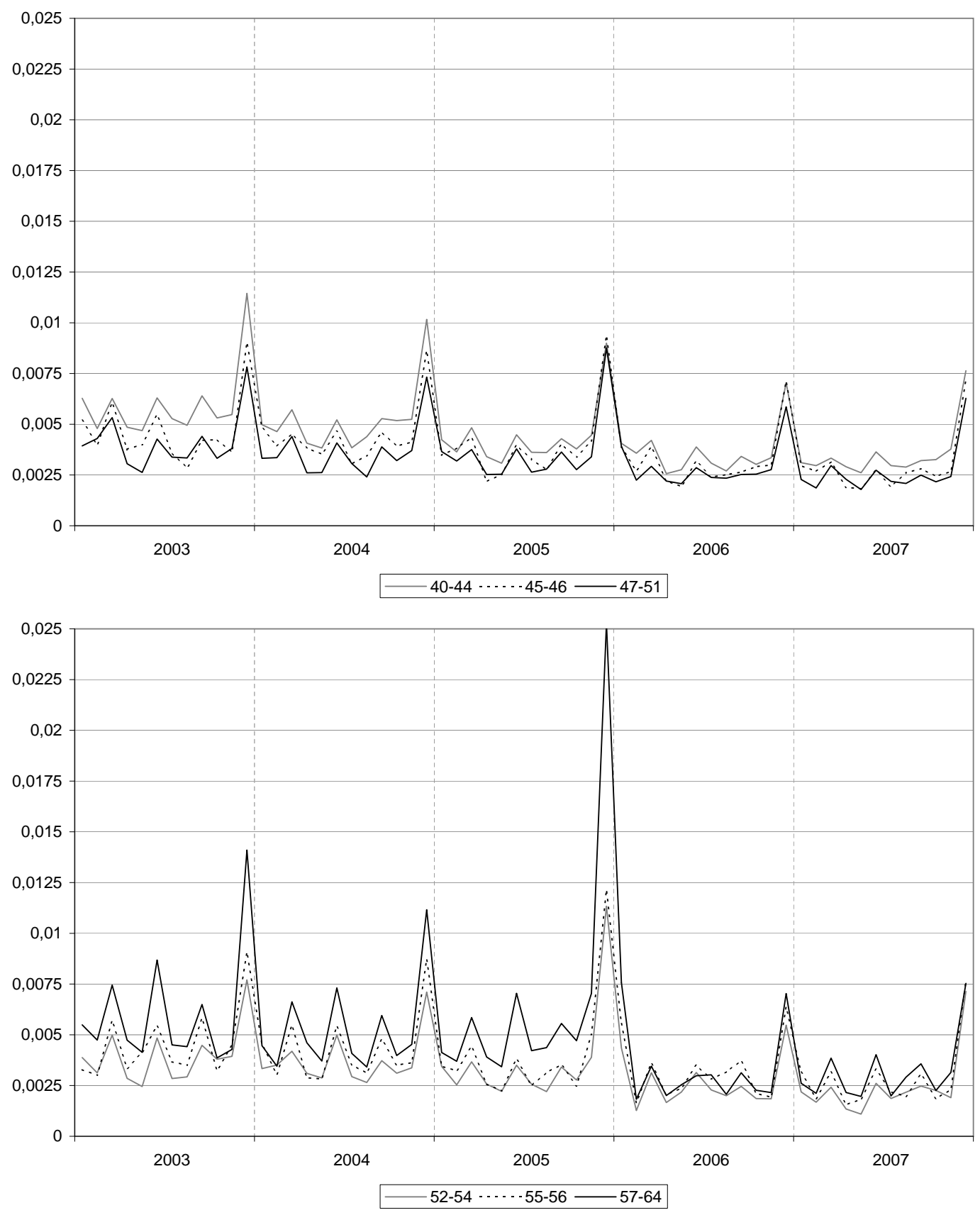


\section{Econometric Analysis}

The descriptive analysis has already provided first insights how the UB reform in 2006 affected the unemployment experiences of older employees with long UB entitlement lengths. In order to obtain an estimate of the reform effect on unemployment incidence, we employ a difference-in-differences (DiD) design with well defined pre- and post-reform periods and treatment and control groups. DiD estimators are a standard approach to evaluate policy changes that affect different groups of individuals differently ${ }^{4}$. The identifying assumption is that group-level omitted variables can be captured by grouplevel fixed effects (e.g. Angrist and Pischke, 2009, Chap. 5.2), in other words that trends in unemployment incidence would have been the same for different age groups in the absence of treatment.

Our analysis also takes into account anticipation behaviour just before the reform. If anticipation takes place, short- and long-term effects of the reform do not have to coincide. While the short-term effect can be directly estimated, the DiD estimator may be a biased estimator of long-term effects: by advancing dismissals from the post-reform period to the pre-reform period, unemployment incidence decreases - for a limited period after the reform - more strongly than in absence of anticipation. Unfortunately, the 23 months post-reform period is not long enough to resolve this issue, which likely induces our DiD estimator to overestimate the magnitude of the long-term effect. Furthermore, the removal of a tax-free allowance for severance pay (see Section 3) at the beginning of 2006 may also affect our estimates.

We model the conditional probability that an employed individual becomes unemployed during the period 2003 to 2007 as

$$
\operatorname{Pr}\left[y_{i t}=1 \mid x_{i t}\right]=\frac{\left.\exp \left[x_{i t} \beta\right)\right]}{1+\exp \left[x_{i t} \beta\right]},
$$

where $x_{i t}$ represents row it of the design matrix for $d$ (dummy coded) variables and the constant. The matrix has $k$ columns; $\beta$ is a $k$ vector of unknown coefficients. We use the standard maximum likelihood estimator for logit models to estimate model 1 for four different specifications (Model O, A, B and C). The vector of explanatory

\footnotetext{
${ }^{4}$ Another popular approach to investigate the effects of UB entitlement lengths is by means of a regression discontinuity design (RDD, e.g. Angrist and Pischke, 2009, Chap. 6). However, RDD is typically not applied to the analysis of policy changes, but rather to estimate the effects of discontinuities in benefit receipt by age under the same regime (e.g. Lalive, 2007, 2008). Furthermore, RDD requires a measurable discontinuity, which identifies the effect of the policy change (Hahn et al., 2001). Anticipation enlarges this discontinuity; thus reform and anticipation effects cannot be disentangled.
} 
Figure 4: Odds ratios of becoming unemployed from logit models compared with a reference worker aged 40 (Model O). Source: IEB, own results.

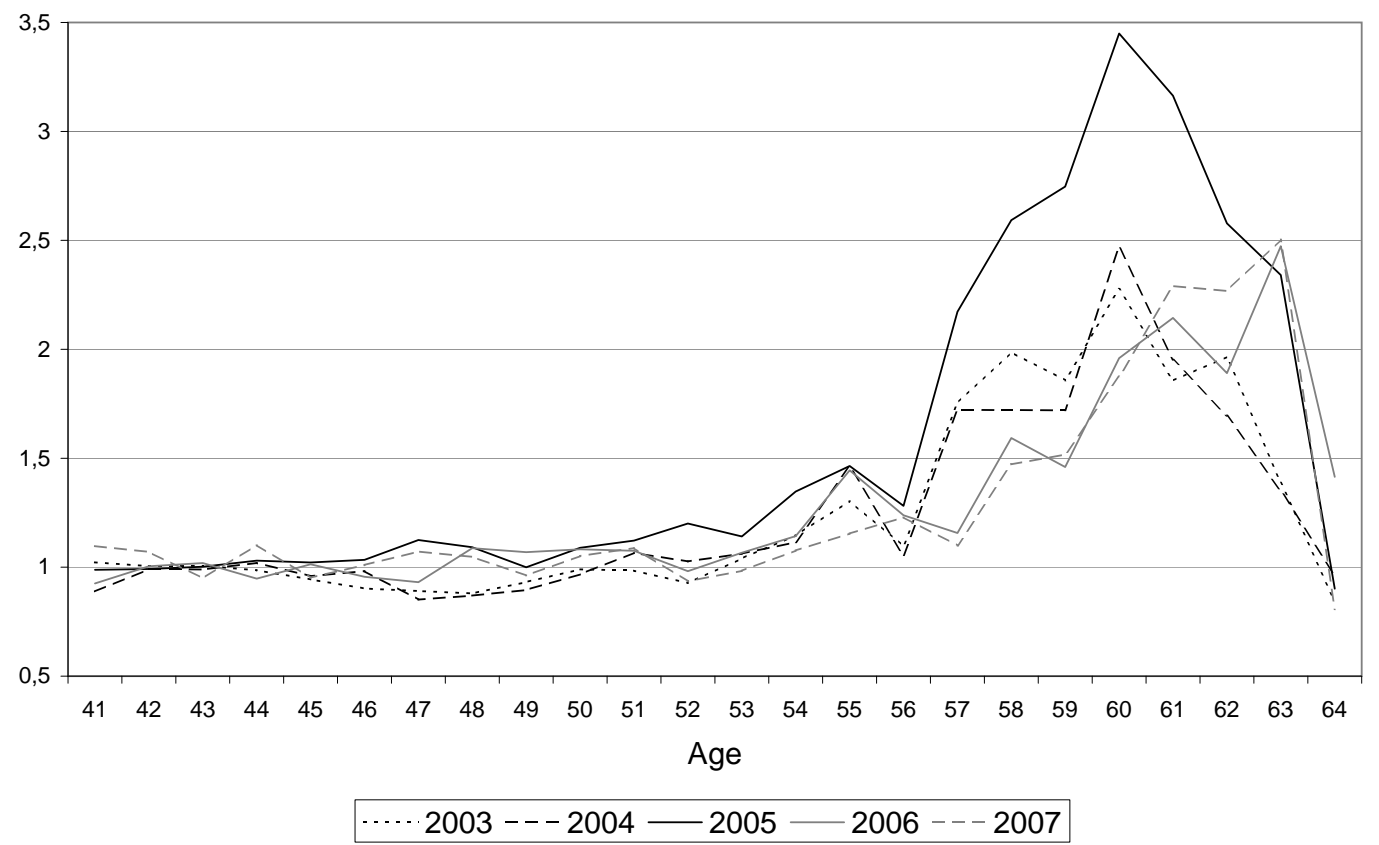

variables $x_{i t}$ includes information on worker's socio-demographic characteristics and work history, firm and region characteristics as well as a number of time dummies. Table 2 summarises the four models, which differ only in the regressor sets ${ }^{5}$. The DiD estimator is implemented in Model B through interactions of age group variables and the postreform dummy, while Model $\mathrm{C}$ includes also interactions between age group variables and the anticipation period.

We first estimate separate logit models for the years 2003 to 2007 (Model O) with age 40 as reference age. Figure 4 presents the resulting age effects in terms of odds ratios. The figure suggests that there are three relevant age intervals. The first ranges from 40 to about 50, where there is no difference in the odds ratios in all years between the age groups. From age 51 to 56 , there is a monotone and parallel increase in odds ratios for all years. The third interval includes those aged $57+$, and it is characterised by larger odds ratios for all years. While pre- and post-reform years form rather homogenous groups, the year 2005 is an outlier with considerably higher odds ratios. They are mainly driven by the anticipation effect of individuals who became unemployed between November and December 2005 (see also Figure 3). Comparing the pre-reform years 2003 and 2004 to the post-reform years 2006 and 2007, we clearly see a downward shift in the

\footnotetext{
$\overline{5}$ More detailed information on the regressors is given in Table 7 (Appendix B).
} 
Table 2: Description of models O, A, B, and C

\begin{tabular}{|c|c|c|}
\hline model & description & \\
\hline$\overline{\mathrm{O}}$ & stratified by year & \\
\hline A & year dummies & \\
\hline $\mathrm{B}$ & basic DiD estimator & \\
\hline $\mathrm{C}$ & DiD estimator with anticipation & \\
\hline variable & description & in model \\
\hline end of year, end of quarter & calender time dummies & $\mathrm{O}, \mathrm{A}, \mathrm{B}, \mathrm{C}$ \\
\hline year dummies & further calender time dummies & $\mathrm{A}, \mathrm{B}, \mathrm{C}$ \\
\hline $\begin{array}{l}\text { female, UB received, high wage, tenure }>4 \\
\text { years, firm size }>500 \text {, employed since } 1993 \text {, } \\
\text { East Germany }\end{array}$ & covariates & $\mathrm{O}, \mathrm{A}, \mathrm{B}, \mathrm{C}$ \\
\hline unskilled, university degree & $\begin{array}{l}\text { education dummies (reference: } \\
\text { skilled worker) }\end{array}$ & $\mathrm{O}, \mathrm{A}, \mathrm{B}, \mathrm{C}$ \\
\hline $\begin{array}{l}\text { food, trade \& services, semi-public services, } \\
\text { public administration }\end{array}$ & $\begin{array}{l}\text { industry dummies (reference: } \\
\text { manufacturing) }\end{array}$ & $\mathrm{O}, \mathrm{A}, \mathrm{B}, \mathrm{C}$ \\
\hline age dummies $(41, . ., 64)$ & age (reference: 40) & $\mathrm{O}$ \\
\hline age group dummies & age groups (reference: $40-44$ ) & $\mathrm{A}, \mathrm{B}, \mathrm{C}$ \\
\hline post-reform & $\begin{array}{l}\text { time dummy for post-reform } \\
\text { period (since February 2006), } \\
\text { base effect }\end{array}$ & $\mathrm{B}, \mathrm{C}$ \\
\hline age group / post-reform interaction dummies & reform effect dummies & $\mathrm{B}, \mathrm{C}$ \\
\hline anticipation period & $\begin{array}{l}\text { time dummy for anticipation } \\
\text { period (November } 2005 \text { until } \\
\text { January 2006) }\end{array}$ & $\mathrm{C}$ \\
\hline $\begin{array}{l}\text { age group / anticipation period interaction } \\
\text { dummies }\end{array}$ & anticipation effect dummies & $\mathrm{C}$ \\
\hline
\end{tabular}


interval 57-61 years. This provides further evidence for considerable changes in unemployment incidence, because results in Figure 4 now control for different compositions of individuals.

Based on these results and given the differences in treatment intensity for age groups (Table 1), we choose the aged 40-44 as the reference group for the pooled regression analysis in Models A-C. Based on Figures 3 and 4, we choose November 2005 to January 2006 as the anticipation period.

As a next step, we estimate Model A, which is a basic reference model with calender year dummies. Table 3 suggests that older employees have a much greater risk of becoming unemployed than individuals aged 40-44. Moreover, it suggests a strongly decreasing unemployment incidence over the course of the years. In particular, there is a downward shift after the year 2005. As this model is not able to separate business cycle effects from effects due to changes in the institutional setup, we next estimate a model that distinguishes between pre- and post-reform regimes for the different age groups (Model B). The basic DiD estimates suggest that the age groups 52-54, 55-56 and 57-64 have a lower transition rate into unemployment after the UB reform. The magnitude of the estimated effect is greater for groups with larger treatment intensity. In particular, the effect appears to be large for the oldest age group (although logit coefficients do not have a direct interpretation). As the presence of anticipation behaviour may directly affect the pre-reform period, we also estimate a model with pre-, anticipation- and post-reform period (Model C). The DiD estimates confirm the results of the descriptive analysis that there is a significant anticipation effect before the reform. Mainly the oldest age groups are affected by anticipation. For the other model coefficients, we observe a high degree of stability over the three model specifications, which is mainly attributed to the large number of observations and the low degree of statistical association with the DiD related variables. We have also estimated several other variants of Model $\mathrm{C}$, which allow for additional variation due to the institutional changes in 2003 (refunding of UB by firms), 2005 (reform of UA) and end of 2007 (subsequent reform of UB), but did not find sizable effects. In particular, the presented results are stable with respect to these model variations.

As logit coefficients do not have a direct interpretation, it is of greater interest to express estimation results in terms of marginal changes in unemployment incidence. The marginal effect of a dummy variable $d$ is defined by

$$
m e(d)=\mathbb{E}_{x}\left(\left[\operatorname{Pr}\left[y_{i t} \mid u\left(x_{i t}, d\right)\right]-\left[\operatorname{Pr}\left[y_{i t} \mid l\left(x_{i t}, d\right)\right]\right)\right.\right.
$$


Table 3: Logit estimates of unemployment incidence

\begin{tabular}{|c|c|c|c|}
\hline variable & Model A & Model B & Model C \\
\hline const & $-4.642^{* * *}$ & $-4.665 * * *$ & $-4.641 * * *$ \\
\hline female & $-0.218^{* * *}$ & $-0.217^{* * *}$ & $-0.218^{* * *}$ \\
\hline UB received since 1993 & $0.819^{* * *}$ & $0.821^{* * *}$ & $0.820^{* * *}$ \\
\hline high wage & $-0.785^{* * *}$ & $-0.785^{* * *}$ & $-0.785^{* * *}$ \\
\hline employment length $>4$ years & $-1.347^{* * *}$ & $-1.346^{* * *}$ & $-1.346^{* * *}$ \\
\hline end of quarter & $0.254^{* * *}$ & $0.265^{* * *}$ & $0.271^{* * *}$ \\
\hline end of year & $0.784^{* * *}$ & $0.784^{* * *}$ & $0.740^{* * *}$ \\
\hline firm size $>500$ & $-0.542^{* * *}$ & $-0.542^{* * *}$ & $-0.542 * * *$ \\
\hline unskilled & $0.119^{* * *}$ & $0.120^{* * *}$ & $0.120^{* * *}$ \\
\hline university degree & $-0.092^{* * *}$ & $-0.093^{* * *}$ & $-0.092 * * *$ \\
\hline employed since 1993 & $0.030^{* *}$ & $0.028^{* *}$ & $0.029 * *$ \\
\hline East Germany & $0.341^{* * *}$ & $0.342^{* * *}$ & $0.342^{* * *}$ \\
\hline food & $0.529 * * *$ & $0.529 * * *$ & $0.530^{* * *}$ \\
\hline trade \& services & $0.168 * * *$ & $0.168^{* * *}$ & $0.168^{* * *}$ \\
\hline semi-public services & $-0.304^{* * *}$ & $-0.303^{* * *}$ & $-0.304^{* * *}$ \\
\hline public administration & $-0.642^{* * *}$ & $-0.641^{* * *}$ & $-0.642^{* * *}$ \\
\hline age group $45-46$ & -0.011 & -0.005 & -0.013 \\
\hline age group $47-51$ & $0.046^{* * *}$ & $0.051^{* * *}$ & $0.040^{* * *}$ \\
\hline age group $52-54$ & $0.122^{* * *}$ & $0.155^{* * *}$ & $0.127^{* * *}$ \\
\hline age group $55-56$ & $0.308^{* * *}$ & $0.336^{* * *}$ & $0.306^{* * *}$ \\
\hline age group 57-64 & $0.701^{* * *}$ & $0.766^{* * *}$ & $0.704^{* * *}$ \\
\hline 2002 & $0.069^{* * *}$ & $0.069^{* * *}$ & $0.069^{* * *}$ \\
\hline 2003 & $-0.022^{*}$ & $-0.022^{*}$ & $-0.022^{*}$ \\
\hline 2004 & $-0.148^{* * *}$ & $-0.148^{* * *}$ & $-0.148^{* * *}$ \\
\hline 2005 & $-0.201 * * *$ & $-0.202^{* * *}$ & $-0.282^{* * *}$ \\
\hline 2006 & $-0.529 * * *$ & $0.066^{* *}$ & $-0.232 * * *$ \\
\hline 2007 & $-0.486^{* * *}$ & $0.170^{* * *}$ & $-0.129 * * *$ \\
\hline post-reform & & $-0.574 * * *$ & $-0.294^{* * *}$ \\
\hline age group $45-46 \times$ post-reform & & -0.029 & -0.021 \\
\hline age group $47-51 \times$ post-reform & & -0.022 & -0.011 \\
\hline age group $52-54 \times$ post-reform & & $-0.155^{* * *}$ & $-0.127^{* * *}$ \\
\hline age group $55-56 \times$ post-reform & & $-0.129 * * *$ & $-0.099 * * *$ \\
\hline age group $57-64 \times$ post-reform & & $-0.315^{* * *}$ & $-0.253^{* * *}$ \\
\hline anticipation & & & 0.002 \\
\hline age group $45-46 \times$ anticipation & & & $0.152^{* * *}$ \\
\hline age group $47-51 \times$ anticipation & & & $0.183^{* * *}$ \\
\hline age group $52-54 \times$ anticipation & & & $0.424^{* * *}$ \\
\hline age group $55-56 \times$ anticipation & & & $0.429^{* * *}$ \\
\hline age group $57-64 \times$ anticipation & & & $0.784^{* * *}$ \\
\hline \# observations & 20408640 & 20408640 & 20408640 \\
\hline McFaddens pseudo- $R^{2}$ & 0.119 & 0.120 & 0.120 \\
\hline \# individuals & 389235 & 389235 & 389235 \\
\hline
\end{tabular}


Table 4: Estimated marginal effects (me) and relative marginal effects (rme) ${ }^{\dagger}$.

\begin{tabular}{cccccc}
\hline \multirow{2}{*}{ period } & age & \multicolumn{2}{c}{ Model B } & \multicolumn{2}{c}{ Model C } \\
& group & me & rme & me & rme \\
\hline pre-reform & $45-46$ & -0.00002 & & -0.00006 & \\
& $47-51$ & $0.00022^{* * *}$ & & $0.00017^{* * *}$ & \\
& $52-54$ & $0.00072^{* * *}$ & & $0.00058^{* * *}$ & \\
& $55-56$ & $0.00170^{* * *}$ & & $0.00152^{* * *}$ & \\
& $56-64$ & $0.00453^{* * *}$ & & $0.00402^{* * *}$ & \\
anticipation & basis & & & 0.00001 & $0.16 \%$ \\
& $45-46$ & & & $0.00071^{* * *}$ & $16.32 \%$ \\
& $47-51$ & & & $0.00087^{* * *}$ & $19.92 \%$ \\
& $52-54$ & & & $0.00227^{* * *}$ & $52.41 \%$ \\
& $55-56$ & & & $0.00231^{* * *}$ & $53.06 \%$ \\
post-reform & $56-64$ & & & $0.00505^{* * *}$ & $117.73 \%$ \\
& basis & $-0.00222^{* * *}$ & $-43.57 \%$ & $-0.00119^{* * *}$ & $-25.36 \%$ \\
& $45-46$ & -0.00013 & $-2.86 \%$ & -0.00009 & $-2.13 \%$ \\
& $47-51$ & -0.00009 & $-2.15 \%$ & -0.00005 & $-1.09 \%$ \\
& $52-54$ & $-0.00063^{* * *}$ & $-14.31 \%$ & $-0.00052^{* * *}$ & $-11.85 \%$ \\
& $55-56$ & $-0.00053^{* * *}$ & $-12.04 \%$ & $-0.00041^{* * *}$ & $-9.37 \%$ \\
& $56-64$ & $-0.00120^{* * *}$ & $-26.95 \%$ & $-0.00099^{* * *}$ & $-22.25 \%$ \\
\hline
\end{tabular}

note: ${ }^{* * *} p<0.01,{ }^{* *} p<0.05,{ }^{*} p<0.1$

$\dagger$ relative to an average reference worker with the same age under the pre-reform regime

where $u\left(x_{i t}, d\right)=\left(x_{i t, 1}, \ldots, x_{i t, d-1}, 1, x_{i t, d+1}, \ldots, x_{i t, k}\right)$, i.e. function $u\left(x_{i t}, d\right)$ replaces the value at position $d$ in vector $x_{i t}$ with one. $l(\cdot, \cdot)$ operates in the same way but puts in a zero. ${ }^{6}$ Furthermore, the magnitude of the marginal effect depends in our framework on the longitudinal frequency (daily, monthly, yearly etc.), and the probabilities and marginal effects on a monthly level are rather small. For this reason, we also report relative marginal effects (rme), which is the marginal effect relative to an average reference individual with the same age in the pre-reform period, i.e.

$$
r m e(d)=\frac{m e(d)}{\mathbb{E}_{x}\left(\left[\operatorname{Pr}\left[y_{i t} \mid \ddot{x}_{i t}\right]\right)\right.} .
$$

$\ddot{x}_{i t}$ is the covariates vector with zeroed reform effect dummies (interactions between age and post-reform). The rme is more informative as it is invariant with respect to panel frequency.

The resulting marginal effects and relative marginal effects for Models B and C are

${ }^{6}$ Cf. Ai and Norton (2003) and e.g. Puhani (2008) for a discussion on marginal effects of interaction terms in nonlinear models. We also computed effects according to Ai and Norton, which were similar to the presented results. 
Table 5: DiD estimators for samples stratified by firm size and length of previous employment (Model C).

\begin{tabular}{|c|c|c|c|c|c|c|c|c|}
\hline \multirow{3}{*}{$\begin{array}{r}\text { age } \\
\text { group }\end{array}$} & \multicolumn{4}{|c|}{ smaller firms } & \multicolumn{4}{|c|}{ larger firms } \\
\hline & \multicolumn{2}{|c|}{ shorter employment } & \multicolumn{2}{|c|}{ longer employment } & \multicolumn{2}{|c|}{ shorter employment } & \multicolumn{2}{|c|}{ longer employment } \\
\hline & me & rme & me & rme & me & rme & me & rme \\
\hline \multicolumn{9}{|l|}{ post-reform } \\
\hline $45-46$ & -0.00083 & $-4.91 \%$ & -0.00006 & $-2.14 \%$ & 0.00121 & $19.54 \%$ & 0.00005 & $-5.01 \%$ \\
\hline $47-51$ & -0.00064 & $-3.76 \%$ & 0.00002 & $-0.55 \%$ & 0.00041 & $6.52 \%$ & -0.00009 & $-10.22 \%$ \\
\hline $52-54$ & $-0.00321 * * *$ & $-18.92 \%$ & $-0.00029 * * *$ & $-9.99 \%$ & -0.00013 & $-2.03 \%$ & -0.00003 & $-3.40 \%$ \\
\hline $55-56$ & -0.00102 & $-6.06 \%$ & -0.00022 & $-7.79 \%$ & -0.00064 & $-10.16 \%$ & $-0.00042^{* * *}$ & $-45.02 \%$ \\
\hline $56-64$ & $-0.00197 * * *$ & $-11.26 \%$ & $-0.00082^{* * *}$ & $-28.30 \%$ & -0.00088 & $-13.98 \%$ & $-0.00050^{* * *}$ & $-51.55 \%$ \\
\hline \# observations & \multicolumn{2}{|c|}{2732024} & \multicolumn{2}{|c|}{12402117} & \multicolumn{2}{|c|}{636951} & \multicolumn{2}{|c|}{4637548} \\
\hline pseudo- $R^{2}$ & \multicolumn{2}{|c|}{0.0578} & \multicolumn{2}{|c|}{0.051} & \multicolumn{2}{|c|}{0.0932} & \multicolumn{2}{|c|}{0.0685} \\
\hline \# individuals & \multicolumn{2}{|c|}{95612} & \multicolumn{2}{|c|}{199935} & \multicolumn{2}{|c|}{18751} & \multicolumn{2}{|c|}{74937} \\
\hline
\end{tabular}

For ease of presentation we do not display the other coefficients of Model C.

reported in Table 4. As has already been mentioned, the strongest effect is observed for the oldest age group. For this group, unemployed incidence is reduced by 0.1 percentage points, which corresponds to a $22.25 \%$ lower incidence in the post-reform period compared to the pre-reform risk. Similarly, the incidence for the age group 52-54 is reduced by 0.05 percentage points or $11.85 \%$, while the partial anticipation effect for the oldest age group is 0.505 percentage points or an increase by $117 \%$. The anticipation effect is in the range of $50 \%$ for the aged $52-56$. These numbers suggest clear evidence for a strong anticipation of the UB reform.

Even though we have already found strong empirical support for the average reform effect being related to the treatment intensity and for the presence of a considerable anticipation of the reform, our second hypothesis that larger firms more likely dismiss their oldest employees with long tenure remains to be analysed. To do so, we estimate Model $\mathrm{C}$ by stratifying the estimation sample with respect to firm size and employment length before unemployment (as a proxy for tenure). The resulting DiD estimators are given in Table $5^{7}$. It is remarkable that smaller firms (less than 500 employees) react in relation to the treatment intensity. In contrast, larger firms merely utilised extended benefit entitlements to generally shed employees aged 55 and older; the drop in unemployment incidence is related to age rather than treatment intensity. As dismissal protection makes it nearly impossible for large firms to dismiss older workers with long tenure due to social criteria, the reform made it more expensive to buy out older workers. Thus the result is in line with our theoretical predictions derived with the theoretical and institutional background sketched in Sections 2 and 3.

7 The full set of estimated coefficients can be obtained by the authors on request. Estimated coefficients of anticipation effects are not displayed, because they are very similar across regimes. 
We also analysed the role of the previous wage (as another indicator for treatment intensity), but we found only weak evidence for stronger effects in the higher quintiles of the earnings distributions. For this reason, we do not present these results.

\section{Fiscal Benefit Analysis}

Our empirical findings suggest that the financial burden for the unemployment insurance decreased due to the UB reform, partly maybe also due to the change in taxation of severance pay. Based on our empirical results, we now estimate per-capita-savings for the unemployment insurance for employees aged 55 and older as well as savings for the entire age cohort. However, the estimates rely on several assumptions: First, we assume that older individuals fully exhaust their UB entitlements, as they are in fact early retired and have a very low probability of re-entering employment (Arntz and Wilke, 2009). This might, however, slightly overestimate the true reform effect. Second, we are interested in the long-run (or steady-state) fiscal benefits of the reform. We cannot, however, identify whether anticipation of the reform led to additional dismissals or whether separations were merely advanced. In the former case, our estimated parameters provide us with the correct long-run effects, while we overestimate the magnitude of long-run effects in the latter case. We can therefore only provide bounds for long-term savings.

Generally, the per capita change in UB costs for an employee aged a (expenditures ${ }_{a}$ ) with maximum entitlement lengths for UB is decomposed (see also Kyyrä and Wilke, 2007) as

$$
\Delta \text { expenditures } s_{a}=p_{a} \Delta \mathbb{E}_{a}(b+s)+\Delta p_{a} \mathbb{E}_{a}(b+s)+\Delta p_{a} \Delta \mathbb{E}_{a}(b+s)
$$

where $p_{a}$ is the probability of becoming unemployed at age $a$ before the reform. $\mathbb{E}_{a}(b+s)$ is the expected cost for the unemployment insurance for an unemployed at age $a$ with maximum entitlement length for UB before the reform. This consists of unemployment benefit transfers $(b)$ and the foregone insurance premium $(s) . p_{a}+\Delta p_{a}$ and $\mathbb{E}_{a}(b+s)+\Delta \mathbb{E}_{a}(b+s)$ are the corresponding post-reform values. $\Delta$ expenditures $_{a}$ is therefore the estimated monthly per capita change in the financial burden for the unemployment insurance, where our decomposition separates the changes due to the reduction in unemployment incidence and the reduction due to shorter UB claim periods. We estimate $p_{a}$ from the data (based on the years 2001-2005). As the level of unemployment benefits $(b)$, we use the age cohort average, based on wages of employees with maximum 
Table 6: Estimated monthly changes in financial burden for the unemployment insurance (based on the post-reform coefficients from Model C)

\begin{tabular}{|c|c|c|c|c|c|c|}
\hline \multirow[b]{2}{*}{ Age group } & \multicolumn{3}{|c|}{$p_{a}$} & \multicolumn{3}{|c|}{$\mathbb{E}_{a}(b+s)$, in Euros } \\
\hline & $40-44$ & $55-56$ & $57-64$ & $40-44$ & $55-56$ & $57-64$ \\
\hline Pre-reform & 0.00437702 & 0.00901464 & 0.01129875 & 13624 & 33956 & 41675 \\
\hline Post-reform & 0.00318492 & 0.00741134 & 0.00912115 & 13624 & 23508 & 23442 \\
\hline Change & -0.0011921 & -0.0016033 & -0.0021776 & 0 & -10448 & -18233 \\
\hline$\Delta p_{a}$ & & -0.0004112 & -0.0009855 & 0 & -10448 & -18233 \\
\hline$\Delta p_{a(\text { anticipation })}$ & & 0.0023085 & 0.0050465 & & & \\
\hline \multicolumn{7}{|c|}{ Per capita changes (in Euros) } \\
\hline Age group & & & & & $55-56$ & $57-64$ \\
\hline $\begin{array}{l}\text { Due to change } \\
\text { Upper bounds }\end{array}$ & expected co & ts. $p_{a} \cdot \Delta \mathbb{E}_{a}($ & $+s)$ & & -73.14 & -148.33 \\
\hline \multicolumn{4}{|c|}{ Due to change in incidence. $\Delta p_{a} \cdot \mathbb{E}_{a}(b+s)$} & & -13.96 & -41.07 \\
\hline \multicolumn{4}{|c|}{ Cross effect. $\Delta p_{a} \cdot \Delta \mathbb{E}_{a}(b+s)$} & & 4.30 & 17.97 \\
\hline \multicolumn{4}{|l|}{$\Delta$ expenditures ${ }_{a}$} & & -82.80 & -171.44 \\
\hline \multicolumn{7}{|c|}{ Total cohort changes (in million Euros) } \\
\hline \multicolumn{4}{|l|}{ Age group } & & $55-56$ & $57-64$ \\
\hline \multicolumn{5}{|c|}{ Number of employees in cohort $(10 / 2005)$} & 906600 & 1614200 \\
\hline \multicolumn{4}{|c|}{ Due to change in expected costs } & & -66.307 & -239.442 \\
\hline \multicolumn{7}{|c|}{ Upper bounds } \\
\hline \multicolumn{4}{|c|}{ Due to change in incidence } & & -12.658 & -66.296 \\
\hline \multicolumn{4}{|c|}{ Cross effect } & & 3.895 & 29.004 \\
\hline \multicolumn{4}{|c|}{ Total savings (lower bound) } & & -66.307 & -239.442 \\
\hline \multicolumn{4}{|c|}{ Total savings (upper bound) } & & -75.071 & -276.733 \\
\hline
\end{tabular}

UB entitlements; furthermore, we assume a joint employer-employee unemployment insurance contribution rate $(s)$ of $5 \%$, as the mean actual contribution rate was close to this value in the period under consideration.

Table 6 shows our resulting estimates. The upper panel of the table reports the per capita changes in unemployment incidence, expected costs and change in the unemployment incidence. For a worker of age 55-56, the savings in expected costs amount to about 10,000 Euros, for a worker of age 57-64 to about 18,000 Euros, provided that workers exhaust their claims. The true change in the incidence level can only be bounded as we cannot identify whether the anticipation effect was caused by additional dismissals or by an advance to earlier periods. The upper bound for $\Delta p_{a}$ is the DiD estimator of 
Model C, which is likely to be greater in magnitude than it would have been in absence of anticipation. The lower bound is 0 , if the entire post-reform effect resulted from an advancing of dismissals. Similarly, the upper bound for the per capita anticipation costs is $3 \cdot \Delta p_{a(\text { anticipation })} \cdot \mathbb{E}_{a}(b+s)$ which is 235 Euros and 631 Euros for the aged $55-56$ and 57-64 respectively. The upper bound of the total anticipation costs is therefore 1,232 millions Euros.

The middle panel of the table reports estimates for the decomposition (4). The major part of the total savings results from the reduction in expected costs. Although we provide only bounds for changes in incidence and the anticipation costs, it is evident form the above figures that the expected savings exceed the anticipation costs after a few months latest. Finally, the lower panel of Table 6 reports the bounds for the monthly (steady-state) savings of the unemployment insurance, given the estimated size of the cohort of employees aged 55-64 with maximum UB entitlement lengths in October 2005. Our numbers suggest that the long-term burden for the unemployment insurance would have been reduced by $(66+239) \cdot 12=3,660$ up to $(75+277) \cdot 12=4,224$ millions Euros per year. Although the major part arises for those aged 57-64 (under the assumption that they fully exhaust UB entitlements), the reduction in the incidence was also likely to be of importance.

Even though the long-term savings would have been rather large, it is important to note that the actual savings due to the change in expected costs started 18 months after the reform (due to anticipation, there was probably even an increase in the actual costs in 2005 and 2006). As the reform was already partly abolished after 23 months, the actual steady state period covers at most 5 months. Nonetheless, our computations clearly suggest that the reduction in UB entitlement lengths had important fiscal consequences. The cut in the entitlement lengths likely explains-apart from improving business conditions and the economic upswing - part of the excellent financial situation of the unemployment insurance in 2007 and early 2008, which was generating a massive surplus during this period. Furthermore, our simple computations ignore savings for younger age cohorts and that budgets of other social insurance branches were likely to be positively affected, too. Of course, however, longer means tested UA claim periods after exhaustion of UB entitlements have caused an additional financial burden for taxpayers. 


\section{Conclusions}

Our paper confirms that extended unemployment benefit entitlement lengths provide incentives for higher unemployment entries - in particular for older workers. Short benefit durations make lay-offs more costly for firms and workers, which discourages the use of unemployment benefits as a pathway into retirement.

It is important to identify the reasons for the low employment rates of older workers in Germany (Arnds and Bonin, 2003). Whether it is due to the institutional design or due to discrimination, such knowledge is essential for the design of successful future policies. The results presented in our paper show that the 2006 reform in Germany was in fact successful in fixing an important leak in the design of the welfare state and barring the pathway into retirement through a period of unemployment. The weak labour market performance of older workers in Germany had therefore been at least partly due to the generous social security system. However, the German voting population tends to prefer a more extensive social security system. Using 2006 survey data, Heinemann et al. (2009) showed that only 18 percent of the German population was in favour of cutting unemployment benefits. Thus, it is not surprising that benefit entitlement lengths were re-extended to up to 24 months in 2008.

While we found evidence for our main hypotheses and important short-term reform effects, there are several unresolved difficulties for a more accurate evaluation of the long-term reform effects. Other institutional changes - regarding the pension system and the taxation of severance pay - that have been conducted during the same period might have contributed to the decline in unemployment entries, too. Furthermore, due to anticipation of the reform, the $\mathrm{DiD}$ approach can be expected to overestimate the magnitude of the long-term reform effect on unemployment incidence. A longer postreform would be required to attenuate this effect. The 2006 reform was, however, already mainly withdrawn at the beginning of 2008. This - as well as the fact that employment data are not available for the time period after 2007 yet-hampers also an investigation of reform effects on unemployment durations and exits from unemployment in different labour market states. For these reasons, an analysis of unemployment duration is left for future research, which will at least be able to benefit from longer observed unemployment periods after the reform. 


\section{References}

Addison JT, Portugal P. How do Different Entitlements to Unemployment Benefits Affect the Transitions from Unemployment into Employment? Economics Letters 2008; 101; 206-209.

Ai C, Norton EC. Interaction Terms in Logit and Probit Models. Economics Letters $2003 ; 80 ; 123-129$.

Angrist JD, Pischke JS. Mostly Harmless Econometrics: An Empiricist's Companion. Princeton Universiy Press: Princeton and Oxford; 2009.

Arnds P, Bonin H. Frühverrentung in Deutschland: Ökonomische Anreize und institutionelle Strukturen. in: Herfurth M, Kohli M, Zimmermann KF (Eds), Arbeit in einer alternden Gesellschaft (Labor in an Aging Society), Leverkusen: Leske+Budrich $2003 ; 65-91$.

Arntz M, Wilke RA. Unemployment Duration in Germany: Individual and Regional Determinants of Local Job Finding, Migration and Subsidized Employment. Regional Studies 2009; 43; 43-61.

Bentolila S, Bertola G. Pensions, Firing Costs and Labour Demand: How Bad is Eurosclerosis? Review of Economic Studies 1990; 57; 381-402.

Boeri T., van Ours J. The Economics of Imperfect Labor Markets. Princeton Universiy Press: Princeton and Oxford.

Cahuc P, Zylberberg C. Labor Economics. MIT Press: Cambridge MA/London; 2004.

Fitzenberger B, Wilke RA. Unemployment Durations in West-Germany Before and After the Reform of the Unemployment Compensation System During the 1980s. German Economic Review 2010 (forthcoming).

Gerlach K, Levine D, Stephan G, Struck O. Fairness and the Employment Contract: North American Regions vs. Germany. Cambridge Journal of Economics 2008; 32; 421-439.

Hahn J, Todd P, Van der Klaauw W. Identification and Estimation of Treatment Effects with a Regression-Discontinuity Design. Econometrica 2001; 69; 201-209.

Hakola T, Määtäne N. Pension System, Unemployment Insurance and Employment at Older Ages in Finland. Prime Minister's Office Publications 2/2009.

Hanel B. Financial Incentives to Postpone Retirement and Further Effects on Employment - Evidence from a Natural Experiment. BGPE Discussion Paper 54/2008.

Heinemann F, Bischoff I, Hennighausen T. Choosing from the Reform Menu Card - 
Individual Determinants of Labour Market Policy Preferences. Jahrbücher für Nationalökonomie und Statistik 2009; 229; 180-197.

Hutchens R. Social Security Benefits and Employer Behaviour: Evaluating Social Security Early Retirement Benefits as a Form of Unemployment Insurance. International Economic Review 1990; 40; 659-678.

Jahn EJ. Do Firms Obey the Law When they Fire Workers? Social Criteria and Severance Payments in Germany. International Journal of Manpower 2009 (forthcoming).

Karlstrom A, Palme B, Svensson I. A Dynamic Programming Approach to Model the Retirement Behaviour of Blue-Collar Workers in Sweden. Journal of Applied Econometrics 2004; 19; 795-807.

Kyyrä T, Wilke RA. Reduction in the Long-term Unemployment of the Elderly - A Success Story from Finland. Journal of the European Economic Association 2007; $154-182$.

Lalive R, van Ours J, Zweimüller J. How Changes in Financial Incentives Affect the Duration of Unemployment. Review of Economic Studies 2006; 73; 1009-1038.

Lalive R. Unemployment Benefits, Unemployment Duration, and Post-Unemployment Jobs: A Regression Discontinuity Approach. American Economic Association Papers and Proceedings / American Economic Review 2007; 97; 108-112.

Lalive R. How do Extended Benefits Affect Unemployment Duration? A regression Regression Discontinuity Approach. Journal of Econometrics 2008; 142; 785-806.

Lee S, Wilke RA. Reform of Unemployment Compensation in Germany: A Nonparametric Bounds Analysis Using Register Data. Journal of Business and Economic Statistics 2009; 27; 176-192.

Moffitt R, Nicholson W. The Effect of Unemployment Insurance on Unemployment: The Case of Federal Supplemental Benefits. The Review of Economics and Statistics $1982 ; 64 ; 1-11$.

Mortensen D. Job Search, the Duration of Unemployment, and the Phillips Curve. American Economic Review 1970; 60; 505-517.

Müller E, Wilke RA, Zahn P. Beschäftigung und Arbeitslosigkeit älterer Arbeitnehmer: Eine mikroökonometrische Evaluation der Arbeitslosengeldreform von 1997. Jahrbücher für Nationalökonomie und Statistik 2007; 227; 65-86.

Oberschachtsiek D, Scioch P, Seysen C, Heining J. Stichprobe der Integrierten Erwerbsbiografien IEBS - Handbuch für die IEBS in der Fassung 2008. FDZ Datenreport $03 / 2009$. 
OECD. Statistical Appendix. Employment Outlook. Paris 2003.

Puhani PA. The Treatment Effect, the Cross Difference, and the Interaction Term in Nonlinear "Difference-in-Differences" Models. IZA Discussion Paper 3478/2008.

Stock JH, Wise DA. Pensions, The Option Value of Work, and Retirement. Economcetrica $1990 ; 58 ; 1151-1180$.

Winter-Ebmer R. Benefit Duration and Unemployment Entry: A Quasi-Experiment in Austria. European Economic Review 2003; 47; 259-273. 


\section{A. Institutional Background Supplement}

Withdrawal from registered unemployment: An important peculiarity to the German labour market were regulations for unemployment compensation claimants aged 58 or older, which made it possible to withdraw from the labour market while still receiving unemployment compensation ( $\$ 428$ SGB III). These inactive unemployment claimants were not part of registered unemployment any longer. This $58+$ rule was extended to elderly without entitlements for unemployment benefits in May 2003 (§252,8 SGB VI). The $58+$ rules were abolished at the end of 2007. Since 2008, a similar rule was enacted for older unemployed UA recipients: They are signed-off from registered unemployment if they have not received a job offer during one year of benefit receipt (§53a SGB II).

Replacement rates: In case of UB, the wage replacement rate amounts to $60-67 \%$ of the previous wage, depending on whether there are dependent children in the household or not. If the level of UB is not sufficient to meet the household's needs and the household have no other means of subsistence, the household is entitled to additional tax funded unemployment compensation (social benefits until 2004 or unemployment assistance since 2005). Thus UB regulations are practically irrelevant for households with a very low income, even in case of positive entitlements. Furthermore, the change in the transfers levels at expiration of UB is also determined by household wealth and other household income. While the level of means-tested UA amounted to $53-60 \%$ of the previous wage until 2004, it became a flat rate in 2005 that equals the level of social benefits. To sum up, the compensation level for poor and low income households should be almost invariant across regimes, which is not the case for wealthier households and individuals with high pre-unemployment wages. Given that our administrative individual data provide only partial information about the household background, it is difficult to predict the wage replacement rate of an employed individual in case of unemployment. For this reason, we are not able to identify the exact treatment intensity in our data.

Reforms of the pension system: Changes in the UB system since the late 1990s were accompanied by changes in the old age pension system that made early retirement more difficult. While the minimum retirement age has been given by 65, until 1997 in particular women and persons that have been unemployed for at least one year had the opportunity to enter early retirement without pension reductions at age 60 . This set incentives for firms and workers to separate when workers became 57 years and 5 months, exhausting 32 months of unemployment benefits. Since 1997, old age pensions were lowered for individuals retiring prior to the minimum age of 65 by 0.3 percentage 
points per month that retirement entry takes places prior to the age of eligibility for the full pension. During a transition period (1997-2004), different birth cohorts could retire with a full pension at different ages; the transition, however, was implemented without discontinuities and over a long time horizon. Furthermore, from 2006 onwards, the earliest entry age into pension due to unemployment has been raised from 60 to 63 years. Again, the reform was implemented without discontinuities and over a transition period (2006-2012). To summarise, it has been possible since 2005 to build a bridge from UB (with maximum duration) into retirement without pension reductions starting from an age of 62 and 5 months, and with maximum pension reductions (18 percent) still from an age of 57 years and 5 months. Since 2006, a transition into early retirement could be achieved without pension reductions for those aged 63 years and 7 months, while the starting age for a transition with pension reductions depends on the age cohort and gradually increases to 61 years and 7 months (with a latter pension reduction of 7.2 percent).

Employment protection legislation and severance pay: Since 2004, employment protection legislation applies to workers employed in firms with more than 10 workers (before: more than 5 workers) and with a tenure of more than 6 months. Layoffs may only be justified, if the firm can state a suitable reason for termination; most firms dismiss workers for economic reasons or offer severance payments. Firms displacing workers for economic reasons have to rank workers according to the criteria age, tenure, family responsibilities and disability. Furthermore, since 2004, the law specifies the amount of severance payments if the firm dismisses the worker for economic reasons, to reduce incentives of dismissed workers to file a lawsuit (the minimum compensation amounts to one half of a monthly gross wage for each year the worker has been employed by the firm). Generally, if older employees with long tenure quit before terms of notice of the lay-off have expired and receive severance pay, UB claims are suspended and delayed by this period ( $\$ 143 \mathrm{a}$ SGB III). Until 2004, the receipt of severance payments was interpreted as indication of a voluntary job loss; since then it does not induce a cut-off period if the employee has been laid off for economic reasons. 


\section{B. Additional Tables}

Table 7: Variables overview

\begin{tabular}{|c|c|}
\hline variable & description \\
\hline female & dummy for sex, indicating 1 for females \\
\hline UB received since 1993 & dummy for having received UB since 1993 \\
\hline high wage & dummy for earning an upper-two-quintiles wage \\
\hline tenure $>4$ years & dummy for currently having a tenure of more than four years \\
\hline end of quarter & dummy indicating the end of a quarter \\
\hline end of year & dummy indicating the end of a year \\
\hline firm size $>500$ & $\begin{array}{l}\text { dummy for working in a firm with more than } 500 \text { employees } \\
\text { (large firm) }\end{array}$ \\
\hline unskilled & dummy for being unskilled \\
\hline university degree & dummy for having any university degree \\
\hline employed since 1993 & dummy for being continuously employed since 1993 \\
\hline East Germany & $\begin{array}{l}\text { dummy for working in the eastern parts of Germany (for- } \\
\text { mer GDR) }\end{array}$ \\
\hline $\begin{array}{l}\text { food, trade \& services, semi- } \\
\text { public services, public admin- } \\
\text { istration }\end{array}$ & $\begin{array}{l}\text { dummies indicating the industry, reference is 'manufactur- } \\
\text { ing' }\end{array}$ \\
\hline age group $45-46, \ldots, 57-64$ & dummies for the age groups, reference is $41-44$ \\
\hline $2002, \ldots, 2007$ & dummies for the years, reference is 2001 \\
\hline post-reform & dummy for the post-reform phase, i.e. since $2 / 2006$ \\
\hline $\begin{array}{l}\text { age group and post-reform in- } \\
\text { teractions }\end{array}$ & $\begin{array}{l}\text { dummies for the interactions between age groups and post- } \\
\text { reform phase }\end{array}$ \\
\hline anticipation phase & dummy for the anticipation phase, i.e. $11 / 2005$ to $1 / 2006$ \\
\hline $\begin{array}{l}\text { age group and anticipation in- } \\
\text { teractions }\end{array}$ & $\begin{array}{l}\text { dummies for the interactions between age groups and antic- } \\
\text { ipation phase }\end{array}$ \\
\hline
\end{tabular}

